Jurnal Pengurusan 61(2021) $121-131$

https://doi.org/10.17576/pengurusan-2021-61-10

\title{
The Mediating Role of Independence in the Relationship between Auditors' Conscientiousness \& Openness and Professional Skepticism
}

\author{
(Peranan Pengantara Kemerdekaan dalam Hubungan antara Kesaksian, Keterbukaan dan Skeptisisme \\ Profesional Juruaudit)
}

Febrina Yahya

Andi Ina Yustina

(Faculty of Business, President University, Indonesia)

Hadi Mahmudah

(Faculty of Economy, 45 Islamic University, Indonesia)

\section{ABSTRACT}

Auditors are encouraged to assess the fraud factor in audit planning, maintain skepticism during the audit, and assess the nature, timing, and extent of the audit procedures. The purpose of this study is to examine conscientiousness and openness to the experience of professional skepticism with independence as a mediating variable. The method used was a survey in a public accounting firm. All hypotheses in this research were supported. Both personalities of conscientiousness and openness to experience have a positive influence on professional skepticism. Thus, auditor independence positively relates to professional skepticism. The results demonstrated that auditor independence partially mediates the relationships of conscientiousness and openness to the experience of professional skepticism. The findings reveal that both personalities stimulate auditor independence, which lead to enhance professional skepticism.

Keywords: Conscientiousness; openness to experience; auditor independence; professional skepticism.

ABSTRAK

Juruaudit didorong untuk menilai faktor penipuan dalam perancangan audit, mempertahankan keraguan selama audit, dan menilai sifat, waktu, dan prosedur audit. Tujuan kajian ini adalah untuk mengkaji kesungguhan dan keterbukaan terhadap pengalaman skeptisisme profesional dengan kebebasan sebagai pemboleh ubah pengantara. Kaedah yang digunakan adalah tinjauan difirma perakaunan awam. Semua hipotesis dalam penyelidikan ini telah disokong. Kedua-dua keperibadian kesadaran dan keterbukaan untuk mengalami mempunyai pengaruh positif terhadap keraguan profesional. Oleh itu, kebebasan juruaudit secara positif berkaitan dengan keraguan profesional. Hasil kajian menunjukkan bahawa kebebasan juruaudit sebahagiannya memantapkan hubungan kesedaran dan keterbukaan terhadap pengalaman skeptis profesional. Hasil kajian juga menunjukkan bahawa kedua-dua keperibadian itu mendorong kebebasan auditor, yang mendorong peningkatan keraguan profesional.

Kata kunci: Kesedaran; keterbukaan pengalaman; kebebasan juruaudit; keraguan profesional

\section{INTRODUCTION}

Professional skepticism is well known as one of the essential elements in the auditing profession. It has long been recognized as the fundamental principle in the auditing profession (Hurtt 2010). In this regard, since auditors are responsible for external users of financial reports, skeptical attitudes must be maintained throughout the audit process. It will help auditors fulfill their responsibility because IAASB (2012) stated that professional skepticism contributes to audit quality.

The case of Garuda Indonesia's 2018 financial statements that do not follow financial accounting standards made us question the auditor's skepticism when auditing these financial statements. This case caused the Indonesian financial services authority to freeze the public accounting firm for one year. This case motivates researchers to conduct this research.
Talking about skepticism, there are limited factors that determine auditors to be more and less skeptical (Hurtt et al. 2013). Skepticism comes from personal traits (Hurtt 2010; Popova 2020). Individuals have a different tendency to trust others. This tendency is correlated with dispositional factors such as trait beliefs, human attitudes, and personality traits (Kramer 1999). Nelson (2009) developed a model for identifying professional skepticism by considering dispositional factors such as traits (problem-solving skills, ethical tendencies, selfconfidence and a tendency to doubt) and incentives (client cost pressure, litigation exposure, and loss of reputation).

Personality traits consist of openness for experience, conscientiousness, extraversion, agreeableness, and Neuroticism. This study examines conscientiousness and openness for experience as factors that affect professional skepticism. This is because Fatke (2019) 
explains that conscientiousness consists of dispositional components such as thoroughness and persistence. An auditor requires these characteristics in every engagement. We only chose conscientiousness and openness to experience because Nelson (2009) developed a model for identifying professional skepticism by considering dispositional factors such as traits. This is supported by a study of Regbiyantari and Narsa (2021) who found that conscientiousness and openness had an effect on professional skepticism. Openness for experience is related to the acceptance of new ideas, approaches, and experiences. Individuals who tend to be open for experience have a higher level of skepticism (Khan \& Hading 2020). They further explain that the characteristics of openness for experience generally correspond to skepticism. This is supported by the research of Briestaker and Wright (2001) who found that experience and innate abilities are essential for audit decisions.

Furthermore, Farag and Elias' (2016) study specifically examined the link between conscientiousness, openness to experience, and professional skepticism. Their study provides evidence that conscientiousness and openness to experience in an individual can give positive effects to professional skepticism. However, the sample population used by Farag and Elias (2016) on their study was undergraduate accounting students who are close to graduation. Then, although this previous study from Farag and Elias (2016) has examined conscientiousness and openness to experience and their influence on professional skepticism, the process through which conscientiousness and openness to experience can affect professional skepticism is still unknown. Those reasons become this current study's motivation to critique the previous study conducted by Farag and Elias (2016).

Auditor independence is an essential factor in discussing professional skepticism. Unfortunately, the research that examined the direct link between auditor independence and professional skepticism is scant (Hurtt et al. 2013). Then, conscientiousness is expected to have a positive relationship with auditor independence because an individual who has conscientiousness tend to do well in their work (Steel, 2007), and auditor independence is essential to audit quality (DeAngelo 1981). In addition to conscientiousness, openness to experience is also expected to be positively related to auditor independence because an individual who has high openness to experience is independent in judgment (Rothmann \& Coetzer 2003). Therefore, they will have higher independence levels.

In this study, professional skepticism focuses on the suspension of judgment. According to Hurtt (2010), suspension of judgment is one of the characteristics that can trigger understanding and can develop other skeptical characteristics. This is supported by Yustina and Sutarsa's (2020) study. These characteristics vary between individuals and throughout the situations (Webster \& Kruglanski 1994). This study focuses on auditors with different abilities in suspending judgment: how conscientiousness and openness to experience impact professional skepticism.

The sample population used in this study was auditors from big four and non-big four public accounting firms in Indonesia, especially in Jakarta. Since Farag and Elias (2016) used accounting students as their sample, in this study, we examined whether the result provided by Farag and Elias (2016) is applicable to the real auditors. Auditors were used as the sample in this research because, according to Chiang (2016), auditors are assumed to have skeptical behavior. This study then analyzes conscientiousness and openness to experience for professional skepticism by introducing auditor independence as the mediating variable. Auditor independence is an important factor in discussing professional skepticism, but regrettably, the research that examined the direct link between auditor independence and professional skepticism is scant (Hurtt et al. 2013). Then, conscientiousness is expected to have a positive relationship with auditor independence because an individual who has conscientiousness tend to do well in their work (Steel 2007), and auditor independence is essential to audit quality (DeAngelo 1981). In addition to conscientiousness, openness to experience is also expected to be positively related to auditor independence because an individual who has high openness is independent in judgment (Rothmann \& Coetzer 2003). Therefore, this individual is expected to have higher independence levels.

\section{LITERATURE REVIEW}

Conscientiousness can be related to auditor independence. Barrick and Mount (1993) stated that conscientiousness is indicated by self-monitoring and an initiative to plan, organize, and carry out the tasks. Meanwhile, according to Watts and Zimmerman (1983), self-monitoring is essential for auditors to maintain their independence, especially in the absence of governmental regulations, an initiative to plan, organize, and carry out their task, providing a high-quality audit, will inhibit them from engaging in activities that endanger their independence (Kinney et al. 2004).

The dependability component related to cautiousness, reliability, and orderliness is also included in conscientiousness (Barrick \& Mount, 1991). Auditors are demanded to provide high-quality audits. They are expected to be independent because they can report a discovered violation in the financial reports (Watts \& Zimmerman 1983). Conscientious auditors are dependable that they will hold independence as their objectivity, and they are able to restrain client pressure to acquiesce a substandard financial reporting. Also, their cautiousness due to reputation concerns will be an incentive for them to act independently. For instance, several historical examples of auditors taking risky 
actions to secure their reputation capital were documented by Watts and Zimmerman (1983).

LePine et al. (2000) stated that people who score high on conscientiousness would be more effective in making decisions than people who score low on conscientiousness. They tend to do an extent in searching for important information and use trial and error in learning how to weigh information appropriately. Those characters will benefit the audit quality and auditor independence since the quality of audits depends on auditors' decisions, and a high-quality audit indicates how independent the auditors are. Regbiyantari and Narsa (2021) found accounting students with conscientiousness who are very careful in the audit process.

Then, conscientiousness is an essential principle of job performance and is considered a central role in the models that explain job performance (Schmidt \& Hunter 1992). It will be another benefit for the audit quality and auditor independence because conscientious auditors are expected to have an excellent job performance, and provide high-quality audits. Thus, the following hypothesis was tested in this research:

$\mathrm{H}_{1}$ Conscientiousness has a positive influence on auditors' independence.

When performing the audit, the auditor will get much information from different sources, which can lead to ambiguity in making decisions (Smith 1999). Therefore, to minimize the ambiguity in making a decision, the auditor needs to look for more information (Smith 1999). The auditor should come out of their comfort zone and put an effort to seek additional information. This means that the personality of openness to experience is necessary for auditors. It makes sense because the auditors who score high on openness to experience tend to have an intellectual curiosity and be independent in judgment (Barrick et al. 2001). Both intellectual curiosity and independence in judgment lead the auditor to collect more evidence to make an accurate decision. This is what auditor independence is all about. Auditors who have a strong sense of independence will treat evidence with great care and will be careful in making a decision (Gendron et al. 2006).

According to Guénin-Paracini et al. (2015), auditor independence is the ability to carry out audits diligently and effectively, regardless of the auditee's behavior. An auditor with an openness for experience personality has characteristics (high creativity, curiosity, and imagination) in the independence referred to GuéninParacini et al. (2015). Auditors with openness to experience personalities are capable of solving problems quickly, with limited information and high uncertainty (Denissen \& Pengke 2008). This is supported by the research of Regbiyantari and Narsa (2021), in which students who have the characteristics of openness to experience are very critical and wise with their audit findings.
The independence of auditors is tested once the auditors are faced with materially misstated financial statements. It is the condition where there is the possibility of disagreement between auditors and their client's management (Rennie et al. 2014). It can lead to conflict between auditors and their client's management (Moore et al. 2006). However, auditors must be free from any client's interest and stay neutral - they must be independent (Moore et al., 2006). They must be brave in facing all possibilities during the audit, including the possibility of conflict with the client's management, and to keep their loyalty to public trust. Therefore, it becomes another reason that the personality of openness to experience is necessary for auditors. Individuals who are more open to experiences tend to seek new experiences and intelligently reflect on what they are facing (McCrae \& Costa 2003). Thus, the following hypothesis was tested in this research:

$\mathrm{H}_{2}$ Openness to experience has a positive influence on auditor independence.

Auditor independence is well known as the audit profession's foundation (Falk et al. 1999). Auditors' ability to maintain independence throughout the audit is essential to an effective audit and the reliability of financial information (Wallman 1996). Hence, this condition simply referred to the general agreement that the audit would be meaningless without independence (Power 1999).

Auditor independence is considered an essential factor in the discussion of professional skepticism because if the auditor lacks independence, it will be impossible for the auditor to approach the audit with an appropriate level of objectivity and professional skepticism (Hurtt et al. 2013). Similar to Hurtt et al. (2013), Chiang (2016) states that auditor independence enhances auditors' ability to be objective and maintain professional skepticism. Therefore, it is critical to examine the impact of auditor independence on the suspension of judgment. Gendron et al. (2006) states that auditor independence involves taking unbiased points of view throughout the performance of an audit engagement. On one side, skeptical auditor tend to postpone their judgment until they have sufficient information or evidence to support an explanation (Hurtt 2010).

The nature of independent auditors to have an unbiased objective point of view drives them to develop strong professional skepticism. An independent auditor will focus more on the impact of their work on the quality and less on the client's interest (Moore et al. 2006). Auditors who have a strong sense of independence are willing to collect more evidence to make an accurate decision (Dogui et al. 2013). This means that auditors who have a strong sense of independence will treat evidence with great care and be careful to evaluate and make a judgment. This is what professional skepticism is about-it postpones the judgment until sufficient 
evidence or information is achieved (Hurtt 2010). Thus, the following hypothesis was tested in this research:

$\mathrm{H}_{3}$ Auditor independence has a positive influence on Professional Skepticism.

Auditors are expected to provide high-quality audits to maintain their reputation. This expectation will inhibit auditors from engaging in activities that endanger auditor independence (DeFond et al. 2002; Reynolds et al. 2004). Auditor independence is considered an essential characteristic of external auditors (Antle 1984). In 1998, the SEC and the accounting profession (AICPA) were officially arranging the Independent Standards Board (ISB). The intention of ISB is to maintain auditor independence by issuing rules that will prevent audit firms from undertaking activities that jeopardize auditor independence (Craswell et al. 2002).

The personalities of conscientiousness and openness to experience are predicted to influence auditor independence. Those predictions are reasonable because, for instance, both personalities of conscientiousness and openness to experience are influential in making the decisions (LePine 2003; Barrick et al. 2001). People who score high on conscientiousness tend to do an extent in searching for important information and use trial and error in learning how to weigh information appropriately (LePine et al. 2000). According to Barrick et al. (2001), people who are open to experience tend to have an intellectual curiosity and be independent in judgment that leads individuals to be willing to collect more evidence to make an accurate decision. Dewi and Dewi (2018) state that auditors who have conscientiousness and openness to experience are able to provide optimal performance. Auditors who have a strong sense of independence will treat evidence with great care and be careful in making decisions (Dogui et al. 2013).

Moreover, auditor independence is also predicted to influence professional skepticism. Gendron et al. (2006) stated that auditor independence involves taking unbiased points of view throughout an audit engagement performance. That unbiased, objective point of view drives them to influence professional skepticism. They will be willing to collect more evidence to make an accurate decision (Dogui et al. 2013). This means that auditors who have a strong sense of independence will treat evidence with great care and be careful to evaluate and make a judgment. We argue that auditor independence has the possibility to mediate the relationships between conscientiousness and openness to experience to professional skepticism. Thus, the following hypotheses were tested in this study:

$\mathrm{H}_{4 \mathrm{a}}$ Auditor independence mediates the relationship between conscientiousness and professional skepticism

$\mathrm{H}_{4 \mathrm{~b}}$ Auditor independence mediates the relationship between openness to experience and professional skepticism

\section{METHODOLOGY}

\section{SAMPLING AND PROCEDURE}

This study used a quantitative approach. The respondents were auditors who work in public accounting firms in Jakarta, Indonesia. The researchers chose auditors in Jakarta because many public accounting firms operate in Jakarta and are affiliated with international public accounting firms. We used a web survey to gather the data and follow the procedure from Dillman (2014). Questionnaire links were distributed to the public relations of each public accounting firm. The total population in this study was 705 auditors.

The measurements of variables used in this research were adopted from international researches (Donnellan et al. 2006; Hurtt 2010; Yuen et al. 2013). All items stated in questionnaires were translated into Bahasa Indonesia, and proceeded to pilot test. We used final semester Accounting students who have completed their internship program in a public accounting firm for the pilot test. According to Hair et al. (2010), the pilot test assures that both researcher and respondents understand the questionnaires.

\section{MEASURES}

Conscientiousness Conscientiousness was measured using items adopted from Donnellan et al. (2006). Sample items of this scale were "I get chores done right away," "I seldom forget to put things back in their proper place," "I do not make a mess of things," and "I like to order." Likert scale was used in this study ranging from $1=$ very inaccurate to $5=$ very accurate. Cronbach's alpha for this variable is 0.710 .

Openness to Experience Openness to Experience was measured using items adopted from Donnellan et al. (2006). Sample items of this scale were "I have a vivid imagination," "I do not have difficulty understanding abstract ideas," and "I am interested in abstract ideas." Likert scale was used in this study ranging from $1=$ very inaccurate to $5=$ very accurate. Cronbach's alpha for this measure is 0.733 .

Auditor Independence Auditor Independence was measured using items adopted from Yuen et al. (2013). Sample items of this scale were "Most of my auditing clients are medium-to-large-sized companies," "My firm has offered services to most of my clients for many years," and "I have a close relationship with some of my clients" were the sample items. Likert scale was used in this research ranging from $1=$ strongly disagree to 5 $=$ strongly agree. Cronbach's alpha for this variable is 0.710 .

Professional Skepticism Professional Skepticism was measured using items adopted from Hurtt (2010). Sample items of this scale were "I take my time when making 
decisions," "I do not like to decide until I have looked at all of the readily available information," and "I wait to decide on issues until I can get more information." Five item-Likert scale was used in this research ranging from $1=$ strongly disagree to $5=$ strongly agree. Cronbach's alpha for this measure is 0.808 .

\section{STATISTICAL ANALYSIS}

To test the hypotheses, this study used Structural Equation Modeling (SEM) with Partial Least Squares (PLS) software. SEM was used to analyze the relationship between the variables in this study because it is suitable to test latent variables. Other reasons to use SEM in this research were because SEM can be used to explore new models or modify hypothesized models (MacCallum 1995), and then SEM also can handle complicated situations even though there is only a small sample size (Sarstedt et al. 2014). SEM has been widely used in the social science literature (Bentler \& Dudgeon 1996) and is often used by accounting researchers (Poznanski \& Bline 1997). Warp PLS software (Version 3.0) is used in this study to run the data.

\section{RESULT}

\section{DEMOGRAPHIC AND DESCRIPTIVE ANALYSIS}

The questionnaires were distributed to auditors from the big four and non-big four public accounting firms in Indonesia. Of more than 200 auditors who received the questionnaire, 177 auditors responded, and only 94 questionnaires were usable. Therefore, the response rate of this research is $53.1 \%$. The auditors came from various public accounting firms in Indonesia such as PwC, EY, Deloitte, KPMG, BDO, Grant Thornton, Kreston, and Moore Stephens. Demographics details of the respondents are presented in Table 1.

Table 2 presented the descriptive statistics including mean, standard deviation, and correlations among the variables that have been examined in this study.

As the researcher had hypothesized, the result shows that conscientiousness is positively related to auditor independence $(\mathrm{r}=0.504, p<0.01)$, while openness to experience is also positively related to auditor independence $(\mathrm{r}=0.266, p<0.01)$. The result also shows
TABLE 1. Demographic data

\begin{tabular}{ll}
\hline$\%$ of respondents & \\
\hline Gender & \\
Male & $54.84 \%$ \\
Female & $45.16 \%$ \\
Age Groups & \\
$21-25$ & $68.82 \%$ \\
$26-30$ & $22.59 \%$ \\
$31-35$ & $6.45 \%$ \\
$36-40$ & $1.07 \%$ \\
$>40$ & $1.07 \%$ \\
Position & \\
Junior Auditor & $53.76 \%$ \\
Senior Auditor & $34.41 \%$ \\
Assistant Manager & $5.38 \%$ \\
Manager & $5.38 \%$ \\
Public Accounting Firm & \\
Big Four & $74.19 \%$ \\
Non-Big Four & $25.81 \%$ \\
\hline
\end{tabular}

that auditor independence has a positive relationship with professional skepticism $(\mathrm{r}=0.550, p<0.01)$.

\section{MEASUREMENT MODEL ANALYSIS}

Validity and Reliability Test The researcher tested the convergent and discriminant validity to evaluate the validity of the construct. Hair et al. (2010) states that convergent validity can be assessed by considering two indicators: loadings and Average Variance Extracted (AVE). The convergent validity can be supported if each indicator was loaded with a value of more than 0.70 and a significant p-value of less than 0.05 (Hair et al. 2013).

All data presented in Table 3 are the data with AVE more than 0.50 . As presented below, the AVE in Table 3 is ranging from the smallest, which is 0.539 , to the highest, 0.723 . The loading value of each indicator is ranging from 0.612 to 0.866 . Table 3 also shows that all values of composite reliabilities exceed the standard value of 0.7 , ranging from 0.822 to 0.887 . Then, the Cronbach's alpha of each variable is higher than the accepted values of 0.7 . In sum, the validity and the reliability test are adequate.

TABLE 2. Descriptive statistic

\begin{tabular}{|c|c|c|c|c|c|c|}
\hline & Mean & SD & $\mathrm{C}$ & OTE & AI & PS \\
\hline 1. Conscientiousness & 4.011 & 0.814 & & & & \\
\hline 2. Openness to Experience & 3.588 & 0.992 & & & & \\
\hline 3. Auditor Independence & 4.068 & 0.777 & $0.504^{* * *}$ & $0.266^{* * *}$ & & \\
\hline 4. Professional Skepticism & 4.057 & 0.789 & & & $0.550^{* * *}$ & \\
\hline${ }^{* * *}$ Significant at $p<0.01$ & & & & & & \\
\hline
\end{tabular}


TABLE 3. Convergent validity

\begin{tabular}{|c|c|c|c|}
\hline Latent Variable & Mean & S.D & Loading \\
\hline \multicolumn{4}{|l|}{ Conscientiousness $-\mathrm{C}(\mathrm{AVE}=0.539 ; \mathrm{CR}=0.822)$} \\
\hline I get chores done right away & 4.115 & 0.691 & $(0.727)$ \\
\hline I seldom forget to put things back in their proper place & 3.296 & 0.973 & $(0.612)$ \\
\hline I like order & 3.892 & 0.758 & $(0.778)$ \\
\hline I do not make a mess of things & 4.204 & 0.745 & $(0.804)$ \\
\hline \multicolumn{4}{|l|}{ Openness to Experience - OTE $(\mathrm{AVE}=0.656 ; \mathrm{OTE}=0.850)$} \\
\hline I have a vivid imagination & 3.819 & 0.736 & $(0.866)$ \\
\hline I am interested in abstract ideas & 2.925 & 1.086 & $(0.691)$ \\
\hline I do not have difficulty understanding abstract ideas & 3.989 & 0.759 & $(0.861)$ \\
\hline \multicolumn{4}{|l|}{ Auditor Independence $-\mathrm{AI}(\mathrm{AVE}=0.635 ; \mathrm{CR}=0.839)$} \\
\hline Most of my auditing clients are medium-to large sized companies & 4.147 & 0.779 & $(0.758)$ \\
\hline My firm has offered services to most of my clients for many years & 4.269 & 0.739 & $(0.858)$ \\
\hline I have a close relationship with some of my clients & 3.753 & 0.717 & $(0.770)$ \\
\hline \multicolumn{4}{|l|}{ Professional Skepticism - PS $(\mathrm{AVE}=0.723 ; \mathrm{CR}=0.887)$} \\
\hline I take my time when making decisions & 4.040 & 0.695 & $(0.844)$ \\
\hline I don't like to decide until I've looked at all of the readily available information & 3.946 & 0.812 & $(0.856)$ \\
\hline I wait to decide on issues until I can get more information & 4.151 & 0.846 & $(0.850)$ \\
\hline
\end{tabular}

TABLE 4. Discriminant validity

\begin{tabular}{llccc}
\hline & $\mathrm{C}$ & $\mathrm{O}$ & $\mathrm{A}$ & $\mathrm{P}$ \\
\hline Conscientiousness & $\mathbf{( 0 . 7 3 4 )}$ & & & \\
Openness to Experience & $0.455^{* * *}$ & $\mathbf{( 0 . 8 1 0 )}$ & & $\mathbf{( 0 . 7 9 7 )}$ \\
Auditor Independence & $0.648^{* * *}$ & $0.480^{* * *}$ & $0.531^{* * *}$ & $\mathbf{( 0 . 8 5 0 )}$ \\
Professional Skepticism & $0.456^{* * *}$ & $0.553^{* * *}$ & & \\
Diagonal element: Square root of AVE; off-diagonal: Correlation between constructs. & & \\
\hline
\end{tabular}

${ }^{* *}$ Significant at $p<0.01$

TABLE 5. PLS result

\begin{tabular}{|c|c|c|c|c|}
\hline Variables & Conscientiousness & Openness to experience & Audit Independence & Professional Skepticism \\
\hline \multicolumn{5}{|l|}{ Direct } \\
\hline Conscientiousness & & & & $0.49^{* * *}$ \\
\hline $\mathrm{R}^{2}$ & & & & $0.24^{* * *}$ \\
\hline Openness to experience & & & & $0.58^{* * *}$ \\
\hline $\mathrm{R}^{2}$ & & & & $0.33^{* * *}$ \\
\hline \multicolumn{5}{|l|}{ Full Model } \\
\hline Conscientiousness & & & $0.50^{* * *}$ & $0.21^{* * *}$ \\
\hline Openness to experience & & & $0.27^{* * *}$ & $0.38^{* * *}$ \\
\hline Audit Independence & & & & $0.55^{* * *}$ \\
\hline $\mathrm{R}^{2}$ & & & $0.47^{* * *}$ & $0.30^{* * *}$ \\
\hline
\end{tabular}

${ }^{* * *}$ Significant at $p<0.01$ 
To assess discriminant validity, this study used square root of AVE which is higher than latent variable correlation. The value on the diagonal sections (the bold numbers) has higher values than those that are not in diagonal section (Fornell \& Larcker 1981). In light of table 4, the discriminant validity had fit the requirement.

\section{STRUCTURAL MODEL ANALYSIS}

The PLS result (table 5) shows that the linkages between conscientiousness and auditor independence are significant (path coefficient $=0.50, \mathrm{p}<0.01$ ), while openness to experience has a significant relation with auditor independence (path coefficient $=0.27, \mathrm{p}<0.01$ ). Hence, Hypotheses $\mathrm{H}_{1}$ and $\mathrm{H}_{2}$ are supported. As we can see in figure 1 , auditor independence demonstrates a positive influence on professional skepticism (path coefficient $=0.55, \mathrm{p}<0.01$ ). Accordingly, $\mathrm{H}_{3}$ is supported.

TABLE 6. VAF test

\begin{tabular}{lcc}
\hline Description & \multicolumn{2}{c}{ Calculation } \\
\hline Indirect effect (C-AI-PS) & $0.650 \times 0.410$ & 0.266 \\
Direct effect (C-PS) & & 0.490 \\
Total effect & 0.756 \\
VAF for C-AI-PS & $0.266 / 0.756$ & 0.347 \\
Indirect effect (OTE-AI-PS) & $0.550 \times 0.320$ & 0.176 \\
Direct effect (OTE-PS) & & 0.580 \\
Total effect & & 0.756 \\
VAF for C-AI-PS & $0.176 / 0.756$ & 0.232 \\
\hline
\end{tabular}

As an additional examination to test auditor independence as a mediating variable, this study used the VAF test (Variance Accounted For). Hair et al. (2013) state that the VAF test is more potent than Sobel's test. If the VAF value is less than 20 percent, then there is no mediating effect, but if the value is between 20 percent to 80 percent, the mediation role is partial. However, a value of over 80 percent means full mediation. As presented in table 6, auditor independence as the mediating variable, whether for conscientiousness and professional skepticism, is 0.347 or 34.7 percent. Meanwhile, auditor independence as the mediating variable between openness to experience and professional skepticism is 0.232 or 23.2 percent. Overall, we can assume that the mediating role of auditor independence is only partial. Subsequently, our mediating test verified our hypotheses $\mathrm{H}_{4 \mathrm{a}}$ and $\mathrm{H}_{4 \mathrm{~b}}$.

\section{DISCUSSIONS}

The results of this study highlight several useful relationships for behavioral accounting literature. It analyzes the correlation between conscientiousness, openness to experience, auditor independence, and professional skepticism. In this study, auditors from big four and non-big four public accounting firms act on behalf of the respondents. It will be an indispensable finding since professional skepticism is a necessary characteristic for auditors, and trait skepticism significantly affects auditors' mindset in conducting an audit. Specifically, this study points to the importance of the link between conscientiousness, openness to experience, and professional skepticism. Based on the results, conscientiousness and openness to experience have a positive effect on professional skepticism. This means that auditors who possess conscientiousness, openness to experience, and high skepticism are likely to succeed in the auditing profession.

The finding shows that conscientiousness has a positive effect on auditor independence. The positive effect of conscientiousness on auditor independence indicates that conscientious auditors will be free from any interest and stay neutral to achieve audit success. It makes sense because conscientiousness is associated with task performance and creativity. Conscientious people tend to do well in the accomplishment of work tasks. Conscientious people who are associated with a strong sense of purpose, obligation, and persistence will perform better than those who are not.

Moreover, LePine et al. (2000) stated that people who score high on conscientiousness would be more effective in making decisions than people who score low on conscientiousness. They tend to do an extent in

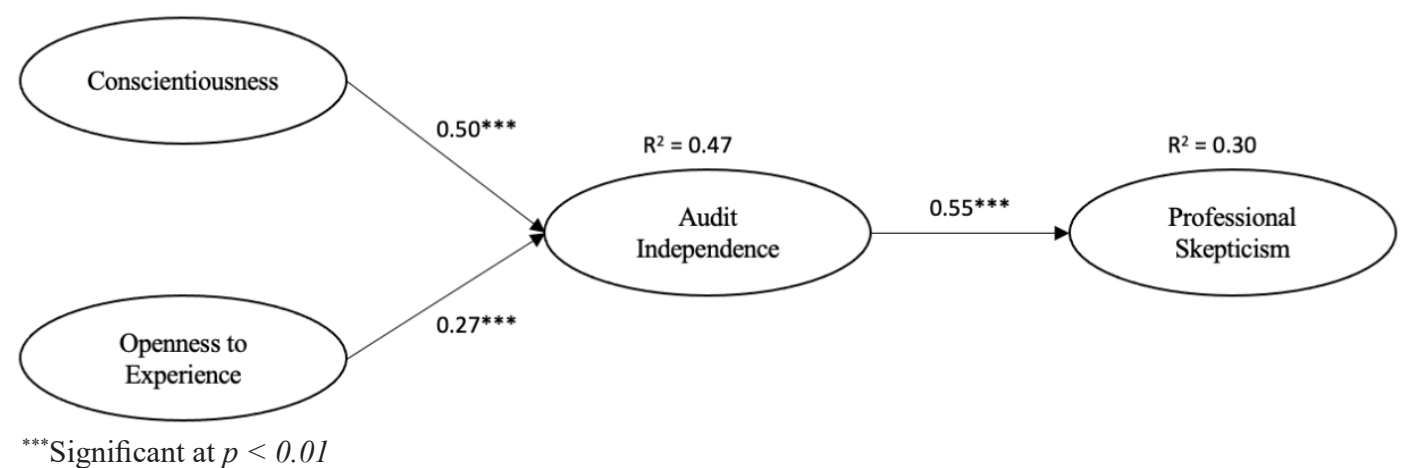

FIGURE 1. Full PLS Model 
searching for important information and use trial and error in learning how to weigh information appropriately. Those characters will benefit the audit quality and auditor independence, since the quality of audits depends on auditors' decisions, and a high-quality audit indicates how independent the auditors are. This finding is consistent with both theories from Steel (2007) and DeAngelo (1981) and proves that conscientious auditors will be more independent. This means that Hypothesis 1 on this research is supported.

The second finding shows that openness to experience has a positive effect on auditor independence. The positive effect of openness to experience on auditor independence indicates that openness to experience people be independent in judgment. Therefore, the tendency of auditors' openness to experience and to be more independent is increasing. This is because openness to experience is related to higher performance and creativity at work. People who are open to experience have an aesthetic sensitivity, active imagination, and variety preference. They believe in the search for knowledge, which is an essential aspect of audit success. This finding is consistent with the theory from Rothmann and Coetzer (2003) and also proves that individuals who are high in openness are independent in judgment. Therefore, they will have higher independence levels. This result supports Hypothesis 2 in this study.

Another finding of this research is congruent with the previous study from Hurtt et al. (2013) that predicted the hypothesis regarding the linkage between auditor independence and professional skepticism. An independent auditor will focus more on the impact of their work on the quality and less on the client's interest (Moore et al. 2006). They are willing to collect more evidence to make an accurate decision (Dogui et al. 2013). This means that independent auditors will treat evidence with great care and be careful to evaluate and make a judgment. They postpone their judgment until sufficient evidence or information is achieved (Hurtt 2010). In addition, this study's finding enriches behavioral literature because, according to Hurtt et al. (2013), the research that examined the direct link between auditor independence and professional skepticism is scant. This study provides evidence that auditor independence is an essential factor in discussing professional skepticism. Thus, Hypothesis 3 in this study is supported.

In this study, auditor independence is proven to be a partial mediator in the relationship between conscientiousness and openness to experience to professional skepticism. Conscientiousness and openness to experience affect auditor independence, applied, and professional skepticism because if they are independent, they will be skeptical. Li et al. (2014) stated that positive personality characteristics affected the performance. They tend to do well in their work, and auditor independence is essential to audit quality. Then, auditor independence is well known as an essential factor in the discussion of professional skepticism. In this study, conscientiousness and openness to experience affect auditor independence, and auditor independence affects auditors to be more skeptical. Thus, the result supports Hypotheses 4a and $4 \mathrm{~b}$ in this study.

\section{IMPLICATION}

Theoretical and practical implications from this study's results are as follows: For theoretical implications, the present study contributes in at least two ways. First, the results provide evidence that auditor independence mediates the relationship between conscientiousness, openness to experience, and their influence on professional skepticism on auditors who have professional skepticism. It increases the understanding of the process through which conscientiousness and openness to experience can affect auditors' professional skepticism. As previously explained, although previous study from Farag and Elias (2016) specifically examined the link between conscientiousness and openness to experience to professional skepticism, the process through which conscientiousness and openness to experience can affect professional skepticism is still unknown. Then, Farag and Elias (2016) provided the result using accounting students who are close to graduation as the sample population. Second, this study provides evidence that auditor independence is a significant factor in discussing professional skepticism. According to Hurtt et al. (2013), the research that examined the direct link between auditor independence and professional skepticism is scant. This means that the result of our study increases the understanding of the linkage between auditor independence and professional skepticism.

For practical implications, the relationship discovered in this research shows that it is essential for organizations to have certain types of auditors in the auditing profession, specifically those with positive personalities, conscientiousness, and openness to experience, independence, and high trait skepticism. Organizations could select independent and skeptical auditors, retain them, and promote auditors with high independence and skepticism inside the organizations. Organizations can do this by utilizing their human resources in hiring auditors selectively and through considerations of positive personalities, independence, and high trait skepticism. They can also provide performance appraisal, training, and development to promote auditor independence and professional skepticism inside the organizations.

\section{CONCLUSION}

This study proposed and examined a theoretical model that attempts to explain how conscientiousness and openness to experience influence professional skepticism via auditor independence. The data were collected from 94 auditors in big four and non-big four public 
accounting firms in Indonesia through a web-based survey. This study used SEM-PLS as statistical analysis tools to test five different hypotheses. All hypotheses developed in this study are supported. The results show positive relationships between conscientiousness and auditor independence, openness to experience and auditor independence, and auditor independence with professional skepticism. Moreover, auditor independence has partially mediated both relationships between conscientiousness and professional skepticism and openness to experience with professional skepticism.

This study contributes to accounting behavioral literature in at least three ways. First, this study examines the effect of conscientiousness and openness to experience toward professional skepticism on auditors that have professional skepticism. This study contributes in practice, i.e., that public accounting firms can apply personality tests to accept prospective auditors to determine the personality traits of prospective auditors. Second, this study found that auditor independence is proven to be a partial mediator in the relationship between conscientiousness and openness to experience to professional skepticism. Based on $\mathrm{Li}$ et al. (2014), positive personality characteristics affect the performance. Therefore, conscientiousness and openness to experience may affect auditors' performance in the audit process. The results suggest that as the positive personality characteristics, conscientiousness and openness to experience could deliver auditors to be independent, so they will be more skeptical and protect themselves from any interest, and stay neutral to achieve audit success. Third, this study contributes to the growing but still limited literature about the linkage between auditor independence and professional skepticism (Hurtt et al. 2013). The result becomes evidence for the predicted hypothesis of Hurtt et al. (2013) regarding the linkage between auditor independence and professional skepticism. These finding may inspire other researchers to examine further the relationship between personality traits and professional skepticism in varied contexts to provide a clearer picture of personality traits in delivering auditors' professional skepticism.

This study has several limitations and recommendations that should be highlighted. First, this study sample was limited to only a specific region in Indonesia, which is Jakarta. It will be difficult to apply the result to other countries or other regions in Indonesia. However, future research should examine the research model in other countries or other regions in Indonesia to be more generalize and reliable.

Second, auditor independence has partially mediated both conscientiousness and professional skepticism and openness to experience with professional skepticism. This means that other variables have the potential to mediate both relationships between conscientiousness and openness to experience with professional skepticism. Thus, future research should examine other variables that have the potential to mediate those relationships because, according to Baron and Kenny (1986), the form of partial mediation is the indicator that there may be other variables that could mediate the relationship between independent and dependent variable. Future research is suggested to examine the locus of control as the mediating variable. According to Ashkanasy (1985), locus of control is influenced by stable characteristics. Therefore, personalities are stable characteristics of individual differences (Hirschberg 1978). Then, Cherry (2006) found that locus of control significantly affects judgment and intentions. This means that locus of control influences professional skepticism because one fundamental component of professional skepticism based on Nelson's model and framework (2009) and Hurtt et al. (2013) is professional skepticism judgment.

\section{REFERENCES}

Antle, R. 1984. Auditor independence. Journal of Accounting Research 22(1): 1-20.

Ashkanasy, N. M. 1985. Rotter's internal-external scale: Confirmatory factor analysis and correlation with social desirability for alternative scale formats. Journal of Personality and Social Psychology 48 (5): 1328-1341.

Baron, R. M. and D. A. Kenny. 1986. The moderator-mediator variable distinction in social psychological research: Conceptual, strategic, and statistical considerations. Journal of Personality and Social Psychology 51(6): 1173-1182.

Barrick, M. R. \& M. K. Mount. 1991. The big five personality dimensions and job performance: A meta-analysis. Personnel Psychology 44(1): 1-26.

Barrick, M. R. \& M. K. Mount. 1993. Autonomy as a moderator of the relationship between the big five personality dimensions and job performance. Journal of Applied Psychology 78(1): 111-118.

Barrick, M. R., M. K. Mount. \& T. A. Judge. 2001. Personality and performance at the beginning of the new millennium: What do we know and where do we go next? International Journal of Selection and Assessment 9: 9-30.

Bentler, P. \& P. Dudgeon. 1996. Covariance structure analysis: Statistical practice, theory and directions. Annual Review of Psychology 47: 563-592.

Bierstaker, J. \& Wright, S. 2001. A research note concerning practical problem-solving ability as a predictor of performance in auditing tasks. Behavioral Research in Accounting 13: 49-62.

Cherry, J. 2006. The impact of normative influence and locus of control on ethical judgments and intentions: A crosscultural comparison. Journal of Business Ethics 68 (2): 113-132.

Chiang, C. 2016. Conceptualizing the linkage between professional skepticism and auditor independence. Pacific Accounting Review 28(2): 180-200.

Craswell, A., D. Stokes., \& J. Laughton. 2002. Auditor independence and fee dependence. Journal of Law and Economics 33: 253-275.

DeAngelo, L. E. 1981. Auditor size and audit quality. Journal of Accounting and Economics 3(3): 183-199.

DeFond, M., K. Raghunandan., \& K. R. Subramanyam. 2002. Do non-audit service fees impair auditor independence? Evidence from going concern audit opinions. Journal of Accounting Research 40(4): 1247-1274. 
Denissen, J. J. A, \& Pengke, L. 2008. Motivational individual reaction norms underlying the Five-Factor model of personality: First steps towards a theory-based conceptual framework. Journal of Research in Personality 42(5): 1285-1302

Dewi, P.P., \& Dewi, I.G.A.P. 2018. Big Five personality, ethical sensitivity, and performance of auditors. International Research Journal of Management, IT \& Social Sciences 5(2): 195-209.

Dillman, D. A., Smyth, J. D., \& Christian, L. M. 2014. Internet, Phone, Mail, and Mixed-Mode Surveys: The Tailored Design Method. Hoboken: John Wiley and Sons.

Dogui, K., O. Boiral., \& Y. Gendron. 2013. ISO auditing and the construction of trust in auditor independence. Accounting, Auditing and Accountability Journal 26(8): 1279-1305.

Donnellan, M. B., F. L. Oswald., B. M. Baird., \& R. E. Lucas. 2006. The mini-IPIP scales: Tiny-yet-effective measures of the big five factors of personality. Psychological Assessment 18: 192-203.

Falk, H., B. Lynn., S. Mestelman., \& M. Shehata. 1999. Auditor independence, self-interested behavior and ethics: Some experimental evidence. Journal of Accounting and Policy 18: 395-428

Farag, M. S., \& R. Z. Elias. 2016. The relationship between accounting students' personality, professional skepticism and anticipatory socialization. Accounting Education 25(2): 124-138.

Fatke, M., 2019. The personality of populists: How the Big Five traits relate to populist attitudes. Personality and Individual Differences 139: 138-151.

Fornell, C., \& D. F. Larcker. 1981. Erratum: Structural equation models with unobservable variables and measurement error: Algebra and statistics. Journal of Marketing Research 18(3): 328-388.

Gendron, Y., R. Suddaby., \& H. Lam. 2006. An examination of ethical commitment of professional accountants to auditor independence. Journal of Business Ethics 64(2): 169-193

Guénin-Paracini, H., Malsch, B. \& Tremblay, M.S., 2015. On the operational reality of auditors' independence: Lessons from the field. Auditing: A Journal of Practice and Theory 34(2): 201-236.

Hair, J. F., W. C. Black., \& B. J. Babin. 2010. Multivariate Data Analysis: A Global Perspective. Upper Saddle River: Prentice Hall.

Hair, J. F., G. T. Hult., C. Ringle., \& M. Sarstedt. 2013. A Primer on Partial Least Squares Structural Equation Modeling (PLS-SEM). New York: SAGE Publications.

Hirschberg, N. 1978. A correct treatment of traits', In Metatheories of Personality, edited by H. Londen, 45-67. New York: Wiley.

Hurtt, R. K. 2010. Development of a scale to measure professional skepticism. Auditing: A Journal of Practice and Theory 29(1): 149-171.

Hurtt, R. K., H. B. Liburd., C. E. Earley., \& G. Krishnamoorthy. 2013. Research on auditor professional skepticism: Literature synthesis and opportunities for future research. Auditing: A Journal of Practice and Theory 32(1): 45-97.

IAASB. 2012. Handbook of International Quality Control, Auditing, Review, Other Assurance, and Related Services Pronouncements.

Khan, J. \& Harding, N., 2020. Facilitating the application of auditors' underlying skeptical disposition. Accounting Research Journal 33(1): 34-56.

Kinney, W. R., Z. Palmrose., \& S. Scholz. 2004. Auditor independence, non-audit services, and restatements: Was the U. S. Government, right.? Journal of Accounting Research 42(3): 561-588.

Kramer, R.M., 1999. Trust and distrust in organizations: Emerging perspectives, enduring questions. Annual Review of Psychology 50(1): 569-598.

LePine, J. A., J. A. Colquitt., \& A. Erez. 2000. Adaptability to changing task contexts: Effects of general cognitive ability, conscientiousness, and openness to experience. Personnel Psychology 53: 563-593.

LePine, J. A. 2003. Team adaptation and post change performance: Effects of team composition in terms of members' cognitive ability and personality. Journal of Applied Psychology 88: 27-39.

Li, N., M. R. Barrick., R. D. Zimmerman., \& D. S. Chiaburu. 2014. Retaining the productive employee: The role of personality. The Academy of Management Annals 8: 347395.

MacCallum, R.C. 1995. Model specification: Procedures, strategies, and related issues. In Structural Equation Modeling: Concepts, Issues, and Applications, edited by R.H. Hoyle. Thousand Oaks, C.A.: Sage,

McCrae, R.R. \& Costa, P.T. 2003. Personality in Adulthood: A Five-Factor Theory Perspective. New York, NY.: Guilford Press.

Moore, D. A., P. E. Tetlock., L. Tanlu., \& M. H. Bazerman. 2006. Conflicts of interest and the case of auditor independence: Moral seduction and strategic issue cycling. The Academy of Management Review 31(1): 10-29.

Nelson, M. 2009. A model and literature review of professional skepticism in auditing. Auditing: A Journal of Practice and Theory 28 (2): 1-34.

Power, M. 2003. Evaluating the audit explosion. Law Policy 25 (3): 185-202.

Popova, V. 2013. Exploration of skepticism, client-specific experiences, and audit judgments. Managerial Auditing Journal 28(2): 140-160.

Poznanski, P. \& D. Bline. 1997. Using structural equations modeling to investigate the casual ordering of job satisfaction and organizational commitment among staff accountants. Behavioral Research in Accounting 9: 154171.

Rennie, M. D., L. S. Kopp., \& W. M. Lemon. 2014. AuditorClient disagreements and Independence: An exploratory field study. Research on Professional Responsibility and Ethics in Accounting 18: 131-166.

Regbiyantari, T. A., and Narsa, N. P. D. R. H. 2021. The role of anticipatory socialization as a mediating variable between the Big Five personality traits and professional skepticism. Jurnal Manajemen Teori dan Terapan 14(1): 83-101.

Reynolds, K., Deis. D. \& Francis, J. 2004. Professional service fees and auditor objectivity. Auditing: A Journal of Practice and Theory 23(1): 29-52.

Rothmann, S., \& Coetzer, E. P. 2003. The big five personality dimensions and job performance. SA Journal of Industrial Psychology 29(1): 68-74.

Sarstedt, M., Ringle, C. M., Smith, D., Reams, R., \& Hair Jr, J. F. 2014. Partial least squares structural equation modeling (PLS-SEM): A useful tool for family business researchers. Journal of Family Business Strategy 5(1): 105-115.

Schmidt, F. L. \& J. E. Hunter. 1992. Development of a causal model of processes determining job performance. Current Directions in Psychological Science 1(3): 89-92.

Steel, P. 2007. The nature of procrastination: A meta-analytic and theoretical review of quint essential self-regulatory failure. Psychological Bulletin 133(1): 65-94. 
Wallman, S. M. H. 1996. The future of Accounting, part III: Reliability and auditor independence. Accounting Horizon 10(4): 76-97.

Watts, R., \& J. Zimmerman. 1983. Agency problems, auditing, and the theory of the firm: Some evidence. Journal of Law and Economics 26(3): 613-33.

Webster, D. M., \&A. W. Kruglanski. 1994. Individual differences in need for cognitive closure. Journal of Personality and Social Psychology 67(6):1049-1062.

Yuen, D. C. Y., P. K. F. Law., C. Lu., \& J. Q. Guan. 2013. Dysfunctional auditing behavior: empirical evidence on auditors' behavior in Macau. International Journal of Accounting and Information Management 21(3): 209-226.

Yustina, A.I. \& Sutarsa, I. K., 2020. The role of professional commitment and suspension of judgment in decreasing auditors' premature sign-off. Jurnal Akuntansi 10(2): 153164.
Febrina Yahya

Faculty of Business

President University

Jl. Ki Hajar Dewantara, Kota Jababeka

Cikarang Baru, Bekasi 17550, INDONESIA

E-Mail: febrinay24@gmail.com

Andi Ina Yustina (corresponding author)

Faculty of Business

President University

Jl. Ki Hajar Dewantara, Kota Jababeka

Cikarang Baru, Bekasi 17550, INDONESIA.

E-Mail: a.inayustina@gmail.com

Hadi Mahmudah

Faculty of Economy

45 Islamic University

Jalan Cut Meutia No. 83, Margahayu

Bekasi 17113, INDONESIA.

E-Mail: hadimahmudah@gmail.com 